\title{
POLLEN GRAIN MORPHOLOGY OF SOME BRAZILIAN SPECIES OF Dorstenia L. (MORACEAE)
}

\author{
Ortrud Monika Barth ${ }^{1}$
}

\section{RESUMO}

Foi estudada a morfologia polínica de 40 espécimens pertencentes à 19 espécies do gênero Dorstenia por meio da microscopia de luz transmitida e a de um número menor de espécies por meio da microscopia eletrônica de transmissão e de varredura. Nāo foi possível caracterizar cada espécie pela morfologia de seus grãos de pólen. Foram estabelecidos três subtipos polínicos segundo o número de poros por grăo; 0 primeiro pode ser subdividido em $D$. brasiliensis, com áspides psilados, e as demais espécies a esta correlacionadas, com áspides espiculosos. Nāo foi encontrada uma correspondên. cia entre os subtipos polínicos estabelecidos, segundo o número de poros por grão, a configuração das superficies e as seçōes taxonômicas. Ficou esclarecida a estrutura das aberturas por meio de cortes ultrafinos, e foi destacada a morfologia típica dos grắos de D. brasiliensis. Foram comentadas algumas tendências evolutivas entre as espécies examinadas, baseadas no número de poros e na estratificação e ornamentação da exina.

\section{ABSTRACT}

The pollen grain morphology of 40 specimens (19 species) of Dorstenia was examined by light microscopy and, for a smaller numer of species, by transmission and scanning electron micros. copy. It was not possible to distinguish each species, on the basis of a particular pollen grain morphology. However, three pollen sub-types were established in relation to the number of pores; within the first, it was possible to separate $D$. brasiliensis, with psilate aspides, from other related species, having spinulate aspides. With regard to surface configuration and the number of pores per grain, no correspondence was found between the pollen sub-types and established taxonomic sections. Aperture construction was elucidated by ultra-thin sections and the special aspect of $D$. brasiliensis pollen grains is here emphasized. Evolutionary trends among the species examined are discussed, based upon number of pores and exine stratification and ornamentation.

\section{INTRODUCTION}

Dorstenia species are preferentially tropi$\mathrm{cal}$, from the lower strata of rain forests. Several papers, from different countries, have touched upon the pollen grain morphology from isolated species, but a general overview of this genus has never been made. The first attempt to establish pollen sub-types was presented by BARTH (in CARAUTA et al., 1979) for eleven Brazilian species. An extensive paper on Dorstenia pollen morphology of African species is in preparation (PUNT, 1986, personal information).

According to CARAUTA (1976), the genus Dorstenia in Brazil is represented by 36 species, most (29 species) coming from the Southeast. Three additional species have been described since then (CARAUTA et al., 1978,
1979; VALENTE et al., 1977) so that about forty species are now known from Brazil.

These species are grouped into four sections (CARAUTA, 1976). The first, Lecania Fisch. \& Meyer, comprises 17 species related to D. turneraefolia Fisch. \& Meyer; the second, Sychinia (Desv.) Fisch. \& Meyer, comprises 4 species related to $D$. ramosa (Desv.) Carauta et al.; the third, Dorstenia, comprises 7 species related to $D$. contrajerva $\mathrm{L}$; , and the fourth, Emygdioa Car., comprises 10 species related to D. brasiliensis Lam.

In order to delimit species and evolutionary trends in this genus, the pollen morphology of 40 specimens was examined by light microscopy and, for many of these, by transmission and scanning electron microscopy as well.

1 Instituto Oswaldo Cruz, Rio de Janeiro, Brasil; Bolsista do Conselho Nacional de Desenvolvimento Centífico e Tecnológico (CNPq). 
Table 1 - Pollen grains from Brazilian Dorstenia species examined. See Material and Methods for explanation of abbreviations.

\begin{tabular}{|c|c|c|}
\hline Species & Collector & Number of pores \\
\hline D. albertorum Car. \& al. & Gurken s/n* (GUA 26.326) & $18(16 \cdot 24)$ \\
\hline D. amazonica Car. \& al. & Carauta 1.863 (GUA) & $16(16-24)$ \\
\hline D. arifolia Lam. & Heringer 21 (SP) & $22(16-24)$ \\
\hline \multirow[t]{3}{*}{ D. asaroides Gardner } & Harley \& Castro 10.949 (RB) & $\geqslant 24$ \\
\hline & Heringer 14.878 (RB) & $16 \cdot 24$ \\
\hline & Prance $s / n$ at. $X .1973$ (RB) & $16-24$ \\
\hline \multirow[t]{6}{*}{ D. brasiliensis Lam. } & Fontella $s / n$ at $28 . X 1.1961$ (SP) & 10 (?) (in MELHEM, 1966) \\
\hline & Handro $s / n$ at $27 . X I .1943$ (SP) & 10 (?) (in MELHEM, 1966) \\
\hline & Hoehne \& Gehrt s/n (SP) & 10 (?) (in MELHEM, 1966) \\
\hline & Toledo s/n at 1948 (SP) & 10 (?) (in MELHEM, 1966) \\
\hline & Rambo 428 (SP) & 10 (?) (in MELHEM, 1966) \\
\hline & Rambo 38.432 (HBR) & $12(10-14)$ \\
\hline \multirow[t]{5}{*}{ D. cayapia Vell. } & Carauta 1.408 (RB) & $13(12 \cdot 16)$ \\
\hline & Duarte \& Gomes 3.725 (RB) & $12-16$ \\
\hline & Emygdio 2.919 \& Emmerich & \\
\hline & 3.457 (RB) & $24(16-24)$ \\
\hline & Sucre 2.026 (RB) & 16 \\
\hline D. contrajerva L. & Ule 6.509 (MG) & $14(12-16)$ \\
\hline D. heringeri Car. \& al. & Heringer 14.880 (RB) & $13(12 \cdot 16)$ \\
\hline D. hildegardis Car. \& al. & Carauta 1.811 (GUA) & $24(16-24)$ \\
\hline \multirow[t]{2}{*}{ D. hirta Desv. } & Frazão $s / n$ at IV. 1916 (RB) & $18(16-24)$ \\
\hline & Sucre $2.170(R B)$ & $12-16$ \\
\hline D. maria Car. \& al. (not published) & Gurken 1.054 (GUA) & $20(16-24)$ \\
\hline D. pernambucana A. Câm. & Pickel 4.183 (SP) & $12(10-12)$ \\
\hline D. ramosa (Desv.) Car. \& al. & Carauta 641 (SP) & $16(10-16)$ \\
\hline D. sabanensis Cuatrec. & Bastos et al. 24 (MG) & $22(16-24)$ \\
\hline D. setosa Moric. & Martinelli 2.284 (SP) & $20(16-24)$ \\
\hline D. tentaculata Fisch. \& Meyer & Heringer $s / n$ at 09.1 .1947 (SP) & $16(16-24)$ \\
\hline \multirow[t]{2}{*}{ D. tenuis Bonpl. ex Bur. } & Smith \& Klein 13.155 (HBR) & $19(16-24)$ \\
\hline & Smith \& Klein 14.111 (HBR) & 16.24 \\
\hline \multirow[t]{2}{*}{ D. tubicina Ruiz \& Pavón } & Huber $s / n$ at III. 1897 (MG) & $16(16-24)$ \\
\hline & Toledo $s / n$ at I.1948 (SP) & $12(10-14)$ \\
\hline \multirow[t]{3}{*}{ D. turneraefolia Fisch. \& Meyer } & Duarte 4.164 (RB) & $\geqslant 24$ \\
\hline & Pereira $2.117(\mathrm{HB})$ & $16(16-24)$ \\
\hline & Sucre 7.751 (RB) & $\geqslant 24$ \\
\hline \multicolumn{3}{|l|}{ D. aff. turneraefolia Fisch. \& } \\
\hline Meyer & Carauta 1.810 (RB) & $24(16-24)$ \\
\hline \multirow[t]{3}{*}{ D. vitifolia Gardner } & Carauta $1.878(\mathrm{RB})$ & $\geqslant 24$ \\
\hline & Hatschbach 32.898 (RB) & $\geqslant 24$ \\
\hline & Pereira et al. 436 (RB) & $\geqslant 24$ \\
\hline D. aff. vitifolia Gardner & Harley et al. 10.990 (RB) & $\geqslant 24$ \\
\hline D. aff. hirta / elata & Mattos 15.692 (SP) & 16 \\
\hline
\end{tabular}

- $s / n=$ "sem número", or fin English) "unnumbered".

\section{MATERIAL AND METHODS}

Pollen grains from herbarium specimens listed in Table 1 were examined. Species names are in accordance with the terminology review. ed by CARAUTA (1976) for Brazilian Dorstenia species. The herbaria that furnished material for this research and their abbreviations used in Table 1 are listed below:

GUA = Herbário "Alberto Castellanos", FEEMA, Rio de Janeiro

$\mathrm{HB}$ = Herbário Bradeanum, Rio de Janeiro

HBR = Herbário "Barbosa Rodrigues", Itajaí, Santa Catarina 


$$
\begin{aligned}
& \text { MG = } \text { Herbário do Museu Paraense Emilio } \\
& \text { Goeldi, Belém, Pará } \\
& \text { RB }= \text { Herbário do Jardim Botânico, Rio de } \\
& \text { Janeiro } \\
& \text { SP }=\begin{array}{l}
\text { Herbário do Instituto de Botânica, São } \\
\text { Paulo. }
\end{array}
\end{aligned}
$$

For light microscopy observations, inflorescence fragments were acetolysed following Erdtman's acetolysis method.

For transmission electron microscopy the acetolysed pollen grains were dehydrated by increasing acetone concentrations, embedded in a standard araldite mixture, cut with a diamond knife on a Sorvall Porter/Blum MT2 ultramicrotome and examined with a Zeizz EM 10 electron microscope.

For scanning electron microscopy, inflorescence pieces were macerated in $70 \%$ ethanol and dispersed by an ultrasonic Bansonic (model 12) apparatus for 15 or 20 minutes. Dehydrated acetolysed grains were also dropped directly on EM-stubs. All were air dried at $37^{\circ} \mathrm{C}$ overnight prior to gold sputtering and observed in a Jeol-25-II SEM.

\section{RESULTS}

The pollen grains of Brazilian Dorstenia species, like other species examined from other countries, are characterized by a great number of round, operculate apertures or pores, always numbering more than 10 , and by a fine spinulous surface ornamentation. There are some variations in pollen grain sizes for the species here examined, but these are not species specific. The diameter of the grains varies from 14 to $22 \mu \mathrm{m}$ and averages $17 \mu \mathrm{m}$. According to literature describing species from other countries, the genus Dorstenia is represented by a unique pollen grain type. We have tried to establish pollen grain sub-types for groups of species according to the number of apertures and the distribution of spinules (Table 1).

The presence of well-definied (Fig. 1D) or poorly defined (Figs. $1 \mathrm{I}$ and $1 \mathrm{~N}$ ) aspidote areas around the apertures cannot be taken into account for sub-type definition, as the age of the pollen grains and the elasticity of their exines at the moment of fixation may be responsible for better or worse morphological definition of the apertural areas (see Figs. 22 and 23 in BARTH, 1984).

For seven species, the same exine stratification was observed by transmission electron microscopy despite variation in the number of supratectal spinules. Between the aperture areas the sexine is tectate, with small short bacula and a spinulate, sometimes nearly granulate tec- tum (Figs. IF and 1R). At the aspides, an "empty" cavity forms by the rise of the tectum and the bacula become loosened from a fine nexine 1. No increase in thickness around the pores was observed in nexine 2 .

The following assembly of specimens based on pollen morphology may be established:

Grains with $10-12$, sometimes 14 pores. This group has the lowest number of pores for the species examined here. Two subgroups may be identified: the first is represented by $D$, brasiliensis (Figs. 1A-1F), with entirely psilate or smooth, more-or-less bilaterally symmetrical aspides of irregular forms and sizes. The second occurs within $D$. pernambucana and $D$. tubicina (Toledo $s / n$ ), but their aspides are more-or-less spinulate or granulate (Figs. 1G-11).

Grains with $12-16$ pores. Only a few spe. cies fall within this group, always with spinulate apertural areas: $D$. contrajerva, $D$. heringeri, $D$. ramosa and one specimen of $D$. hirta. Their aspides present a variable number of spinules, less abundant than within the interapertural areas (Figs, 1J-1R).

Grains with $16-24$ pores. This is the most common pollen morphology (Figs. $2 \mathrm{~A} \cdot 2 \mathrm{H}$ and $3 \mathrm{~A}-3 \mathrm{E})$, represented by a great number of species. Their aperture areas are always considerably spinulate (see Table 1).

Grains with more than 24 pores. Very similar to the preceding pollen group, this group is characterized by grains whose surfaces are entirely occupied by spinulate aspides. It is represented by $D$. turneraefolia and also includes $D$. vitifolia (Figs. 3D-3I).

\section{DISCUSSION}

The pollen morphology of numerous genera of the Moraceae family has been des. cribed by various authors in different papers, as in STRAKA (1966), BARTH et al. (1975, 1976b), HAMILTON (1976), NIEZGODA \& NOWACZYK (1976), RAMOS-ZAMORA (1977), PUNT \& EETGERINK (1982), MIYOSHI (1983) and BARTH (1984). These authors all agree that Dorstenia has a special pollen morphology among the Moraceae genera that, in view of its high number of pores, occupies the most evolved position in this family. In this respect, if one considers solely the genus Dorstenia, D. turneraefolia and $D$. vitifolia present the greatest number of pores, and $D$. brasiliensis the lowest, so that the former two species would seem to be the most highly evolved and the latter the least developed of the species here examined.

Between the pollen grain groups esta- 
blished formally in this paper and the taxonomic sections described by CARAUTA (1976), no complete correspondence of species distribution can be observed. Sometimes the palynological data are in accordance with the taxonomy, as for $D$. brasiliensis and $D$. pernambucana, but $D$. tenuis, from the same section, has a higher number of pores. Similar observations apply to the other pollen groups as well.

Formerly, several Brazilian species had their pollen grain morphology examined by light microscopy (MELHEM, 1966; BARTH, 1976a; VALENTE et al., 1977), but their exine stratification has remained unclear. Within the apertures, operculi must always be present; this does not agree with light microscope observations made on Dorstenia species from Mexico by RAMOS-ZAMORA (1977); it may be that strong acetolysis action dislocated the operculi. On the other hand, there are no vestibuli at the apertures, as supposed by STRAKA (1966), nor any configuration resembling annuli (HAMILTON, 1976).

No increase of the thickness of exine strata has been observed by electron microscopy, only a separation between two layers similar to the air-sacci of some gymnosperm pollen grains. MARTÍNEZ-HERNÁNDEZ et al. (1979) present transmission electron micrographs of 6 species from 6 different Moraceae genera; none has a structure similar to Dorstenia, which they did not examine. Thus, only by the aid of electron microscopy of ultra-thin sections has it become possible to resolve these questions.

The alteration of exine stratification between the apertural and inter-apertural areas in Dorstenia pollen grains may be considered as an advanced character for this genus, whereas the simple endexine (or nexine 2), with constant thickness even around the pores, must be interpreted as signs of primitivism.

In this respect, the special morphology of the grains from $D$. erythandra Grisebach (Punt. 1986, personal information) from Africa, with 12-16 pores, but without aspides, must be taken into account; these grains present an irregular number of smooth "blebs" (in surface view similar to large verrucae) between the pores, that have also formed by the separation of bacula from nexine 1. Occacionally these "blebs" also occur in D. brasiliensis grains (Fig. 1E).

When considering the number of pores, we agree with the data obtained by Punt (personal information) with respect to $D$, turneraefolia and to the specimen Swerdtfeger 9080 from Brazil. A different number of pores (13. 17) was obtained by RAMOS-ZAMORA (1977) for $D$. drakeana ( $D$. arifolia), while we found $22(16-24)$ pores, and $12(10-14)$ for the specimen McVaugh 20.376 from Mexico (slide received by Punt); hence, this species is palynologically not well defined. BURGER \& NIEZ. GODA (1976) present a beaultiful scanning electron micrograph of $D$. contrajerva with about 16 pores, while RAMOS-ZAMORA (1977) observed 10-17 pores; these data are in accordance with our observations on this species.

With respect to the species listed in Table 1 , and taking into account the monograph of BERG (1973) and information received from PUNT (1986), some of the species names do not agree with the taxonomic terminology established by CARAUTA (1976: CARAUTA et al., 1978, 1979; VALENTE et al., 1977 and CARAUTA, 1986, personal information).

Examination of pollen grain morphology may help resolve some questions. For example, D. amazonica has been considered synonymous with $D$. brasiliensis. From the point of view of pollen morphology, however, they cannot be grouped together.

$D$. asaroides corresponds to $D$. cayapia ssp. asaroides in accordance with the specimen Heringer 14.878 and Prance $s / n$, but differs from the specimen Harley \& Castro 10.949, whose grains have the same number of pores as D. vitifolia (D. cayapia ssp. vitofolia).

$D$. cayapia is the same as $D$. Cayapia ssp. cayapia, especially the specimens Carauta 1.408 and Duarte \& Gomes 3.725 .

$D$. heringeri cannot be included in $D$, brasiliensis, nor in $D$. pernambucana, $D$. sabanensis or $D$. tubicina in view of its pollen morphology. $D$. brasiliensis and $D$. pernambucana have very similar pollen morphology in terms of number of pores, but they clearly differ in aspide ornamentation.

D. vitifolia is also given as $D$. cayapia ssp. vitifolia, but, once again, pollen morphologies are different.

The grains of $D$. tentaculata and $D$. arifolia are very similar.

The fewest number of pores (8-12) in the Moraceae was found in two species of Scyphosyce, a genus closely related to Dorstenia; for the genus Craterogyne, synonymous with Dorstenia, the pollen morphology is similar (PUNT, 1978). Examining several African species of Dorstenia, special attention must be paid to D. harmsiana (PUNT, 1978), whose pollen grains present a higher number of pores than any of the species here examined, which has prompted Punt to state that "it seems as if all aspides are fused together". A similar observa- 
tion was made by HAMILTON (1976) for $D$. benguellensis, $D$, holstii and Craterogyne. It shall be interesting to examine the detailed exine stratification of these pollen grains. From the above observations, it seems likely that pollen sub-types other than the American ones may be established for the African species.

\section{CONCLUSIONS}

Pollen grain dimensions are of no taxonomic importance in the species of Dorstenia examined here.

The number of pores per grain are not species specific; they do have some importance, however, in excluding some exsiccata from well-known species. Sometimes the number of pores can separate related species. As a general rule, the limit of pore numbers for an exsicca. ta must be the same for all others of the same species.

As the number of pores is not constant for a certain species, nor is it species specific, and given the frequent superposition of formerly established pollen groups, it shall be more appropriate to distribute the studied Brazilian species among the following three pollen subtypes:

a) few pores per grain $(10-16)$, with occasionally irregularly formed bilateral aspides, with or without supratectal spinules, as in $D$. brasiliensis (with psilate aspides), D. cayapia, $D$. contrajerva, D. heringeri, D. hirta (Sucre $2.170), D$. pernambucana, $D$. ramosa and $D$. tubicina (Tole do $\mathrm{s} / \mathrm{n}$ ) (with spinulous aspides).

b) grains with 24 or more pores, with circular spinulate aspides, as in D. turneraefolia and $D$. vitifolia. c) number of pores per grain varying between 16 and 24 for each species. with circular spinulate aspides, as in all the other species examined.

With respect to evolutionary trends in the Brazilian species examined, a sequence from simple to more complex pollen morphology can be distinguished:

a) $D$. brasiliensis has the smallest number of pores.

b) The presence of smooth "blebs" in the exine of $D$. brasiliensis pollen grains, as well as the smooth aspides around their pores, puts this species at a lower level than $D$. permambucana and the other related species and specimens.

c) On the basis of its great number of pores and densely spinulous surfaces, D. tur neraefolia and $D$. vitifolia have achieved the highest level of differentiation.

\section{ACKNOWLEDGEMENTS}

I especially wish to thank my colleague J.P.P. Carauta for herbarium material and also for long years of interest in my pollen grain re. search on the Moraceae family. I am also grateful to Dr. W. Punt (Utrecht), who sent me slides and micrographs of some American species considered here; also to Dr. T.S. Meihem (São Paulo) for some herbarium specimens; to Ms. Maria da Penha R. da Costa for all photographic reproductions; to the staff of the Laboratory of Electron Microscopy, Biophysical Institute, Federal University of Rio de Janeiro, for the use of their sputtering and scanning electron $\mathrm{mi}$ croscope equipment; and to Dr. T.R. Fairchild for reviewing the manuscript.

\section{REFERENCES CITED}

BARTH, O.M. (1976a) Catálogo sistemático dos pólens das plantas arbóreas do Brasil meridional. XXIII. Moraceae. Mem. Inst. Oswaldo Cruz, 74(3-4): 295-309.

BARTH, O.M. (1976b) Catálogo sistemático dos pólens das plantas arbóreas do Brasil meriđional. XXIV. Urticaceae. Mem. Inst. Oswaldo Cruz, 74(3-4): 341-346.

BARTH, O.M. (1984) Surface morphology of Brazilian Moraceae pollen grains. Bol. IG-USP, 15: 142-149.

BARTH, O.M.; MACIEIRA, E.G.; CÔRTE-REAL, S. (1975) Morfologia do pólen anemófilo e alergisante no Brasil. Casuarinaceae, Salicaceae, Moraceae, Ulmaceae e Urticaceae, Mem. Inst. Oswaldo Cruz, 73(3): 141-152.

BERG, C.C. (1973) Some remarks on the classification and differentiation of Moraceac. Meded. Bot. Mus. Herb. Ryjksuniv. Utrecht, 386:1-10.

BURGER, W. \& NIEZGODA, C. (1976) Pollen. Field Museum Bulletin, September, 1976.

CARAUTA, J.P.P. (1976) Dorstenia L (Moraceae) do Brasil e países limítrofes. Thesis (Federal University of Rio de Janeiro).

CARAUTA, J.P.P.; VALENTE, M. da C.; BARTH, O.M (1978) Dorstenia hildegardis sp. nov, e D. setose, dois acréscimos para as Moraceae do Espirito Santo. Rev. bras. Biol., 38(3):613-618. 


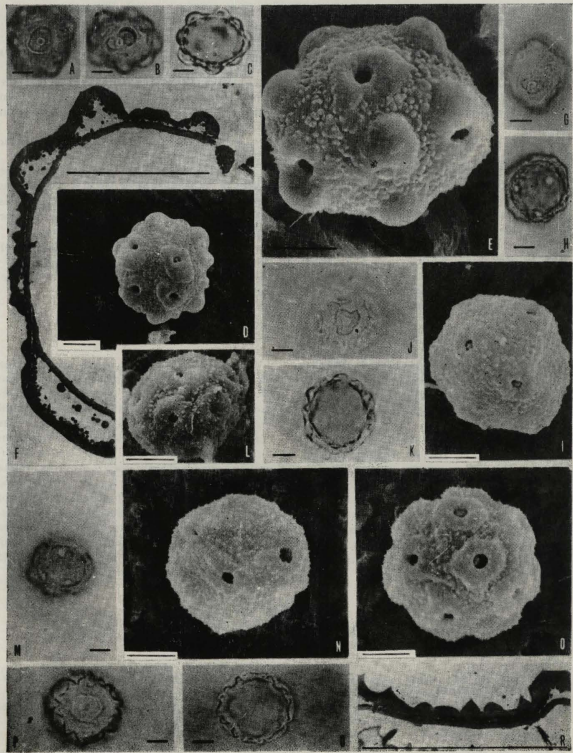

Figura 1 - Abbreviations: LM = light micrograph; SEM = scanning electron micrograph, TEM $=$ transmis. sion electron micrograph. Bar $=5 \mu \mathrm{m}$. (A.F) Dorstenia brasiliensis. (A) Round aperture. LM. 1000x. (B) Aperture area with bilateral symmetry. LM. 100x. (C) Optical section with circular nexine and undulate tectum. LM. 100x. (D) Surface and smooth aperture areas. SEM. 1600x. (E) A "bleb" between aperture areas. SEM. 3200x. (F) Section across an aperture center with operculum (right), interaperture areas and lateral aperture areas with undulate tectum, round bacula of different thicknesses in cross section and exine holes. TEM. 7500x. (G-H) D. pernambucana. (G) Surface. LM. 1000x. (H) Optical section. LM. 1000x. (1) D. tubicina. Young pollen grain with low aperture areas. SEM. 2400x. (J-L) D. cayapia (J) Surface. LM. 1000x. (K) Optical section. LM. 1000x. (L) Surface and apertures. SEM. 2400x. (M-N) D. contrajerva. (M) Surface. LM. 1000x. (N) Surface and apertures. SEM. 2400x. (O) D. ramosa. Surface and apertures. SEM. 2400x. (P-R) D. hirta (P) Surface. LM. 1000x. (Q) Optical section. LM. $1000 x$. (R) Cross section of interapertural exine. TEM. 10,500x. 


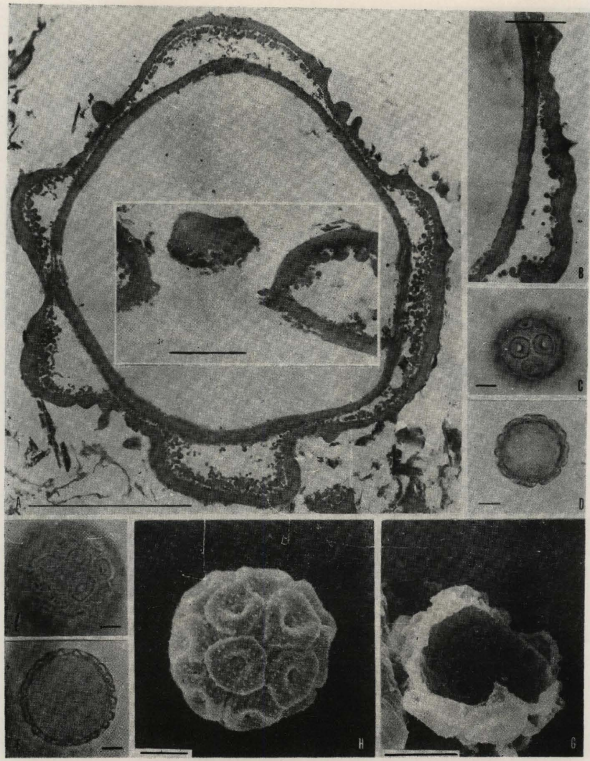

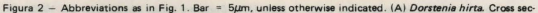
tion of a pollen grain. TEM. $8300 \mathrm{x}$. Inset: cross section through an operculate pore. TEM. 19500x. Bar $=1 / \mathrm{Hm}$. (B) $D$. amazonica. Cross section of interapertural exine (above) with larger spinules than at beginning apertural area (center). TEM. 15000x. Bar = 1 Mm. (C-D) D. arifolia (C) Surface. LM. 1000x. (D) Optical section. LM. 1000x. (E.F) D. asaroides. (E) Surface. LM. 1000x. (F) Optical section. LM. 1000x. (G) D. setosa. Inner exine with pores and broken aperture areo. SEM. $3600 \mathrm{x}$. (H) D. tentaculata. Surface and apertures. SEM. $2400 \mathrm{x}$. 


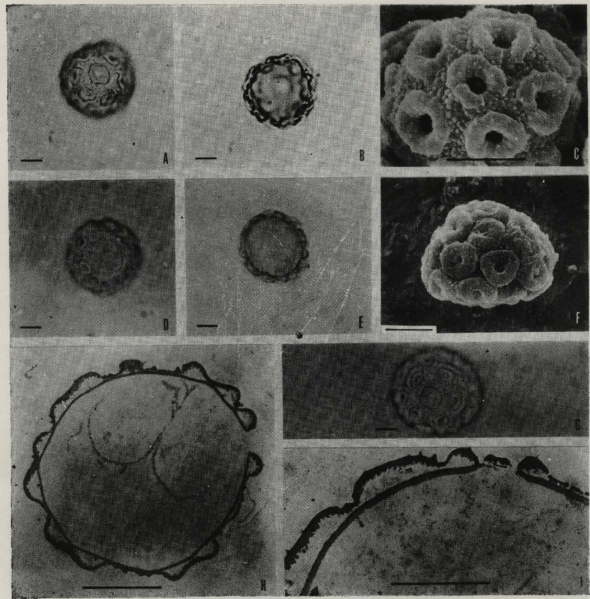

Figura 3 - Abbreviations as in Fig. 1. Bar - 5um. (A-C) Dorstenia tenuis. (A) Surface. LM. 1000x. (B) Optical section LM. 1000x. (C) Surface and apertures. SEM. 3750x. (D-E) D. Maria. (D) Surface. LM. 1000x. (E) Optical section. LM. 1000x. (F) D. vitifalia. Surface and apertures. SEM, 2400x, (G-1) 0 turneraefolia. (G) Surface. LM. $1000 x$. (H) Cross section of a polien grain, at right of an open aperture. TEM. $4000 x$. (I) Cross section of an aperture with operculum. TEM. 5000x. 
Paleobot. Palinol. na América do Sul - 1985 - Bol. IG-USP, Inst. Geociênc., Univ. S. Pauio, 17: 1-147, 1986

CARAUTA, J.P.P.; VALENTE, M. da C.; BARTH, O.M. (1979) Dorstenia L. (Moraceae). Notas Complementares III. Arq. Jard. Bot. Rio de Janeiro, 23: 105-113.

HAMILTON, A.C. (1976) Identification of east African Urticales pollen. Pollen et Spores, 18(1):27-66.

MARTINEZ-HERNÁNDEZ, B; VARGAS-OLVERA, M; LUDLOW-WIECHERS, B. (1979) Ultraestructura de la exina en granos de polen en Angiospermas. Biotica, 4(1): 33-48.

MELHEM, T.S. (1966) Pollen grains of plants of the "Cerrado", XII. Cucurbitaceae, Menispermaceae and Moraceac. An. Acad. brasil. Ciênc., 38(1): 195-203.

MIYOSHI, N. (1983) Pollen morphology by means of scanning electron microscope. 6. Urticales (Angiospermae). Bull. Hiruzen Res. Inst., 8:41-53.

NIEZGODA, C.J. \& NOWACZYK Jr. (1976) Palynological studies in Acanthinophyllum. Clarisia, Sorocea and Tro. phis (Moraceae). Pollen et Spores, 18(4):513-522.

PUNT, W. (1978) On the pollen morphology of Scyphosyce and Dorstenie (Moraceac). Grana, 17: 77-79.

PUNT, W. \& EETGERINK, E. (1982) On the pollen morphology of some genera of the tribe Moreae (Moraceae). Grana, 21:15-19

RAMOS-ZAMORA, D. (1977) Morfologia de los granos de pólen de la familia Moraceae en México. Bol. Soc. Bot. México, 36:71-92.

STRAKA, H. (1966) Palynologia Madagassica et Mascarenica. Fam. 50-59 bis. Pollen et Spores, 8(2): 241-264

VALENTE, M. da C.; CARAUTA, J.P.P.; BARTH, O.M. (1977) Comentários sobre algumas espécies de Dorstenia $\mathrm{L}$. (Moraceae) da América do Sul meridional. Rey. brasil. Biol, 37(1): 167-173. 